\title{
Universiteit
}

Leiden

The Netherlands

\section{How radical environmental sabotage impacts US elections}

Farrer, B.; Klein, G.R.

\section{Citation}

Farrer, B., \& Klein, G. R. (2019). How radical environmental sabotage impacts US elections.

Terrorism And Political Violence. doi:10.1080/09546553.2019.1678468

Version: $\quad$ Publisher's Version

License: $\quad$ Leiden University Non-exclusive license

Downloaded from: https://hdl.handle.net/1887/3238773

Note: To cite this publication please use the final published version (if applicable). 


\section{(1)}

\section{How Radical Environmental Sabotage Impacts US Elections}

\section{Ben Farrer \& Graig R. Klein}

To cite this article: Ben Farrer \& Graig R. Klein (2019): How Radical Environmental Sabotage Impacts US Elections, Terrorism and Political Violence, DOI: 10.1080/09546553.2019.1678468

To link to this article: https://doi.org/10.1080/09546553.2019.1678468

曲 Published online: 04 Nov 2019.

Submit your article to this journal $x$

Шll Article views: 185

Q View related articles $₫$

View Crossmark data \ulcorner 


\title{
How Radical Environmental Sabotage Impacts US Elections
}

\author{
Ben Farrer (10) and Graig R. Klein (10 ${ }^{\mathrm{b}}$ \\ ${ }^{a}$ Department of Environmental Studies, Knox College, Galesburg, Illinois, USA; ${ }^{b}$ Department of Professional \\ Security Studies, New Jersey City University, Jersey City, New Jersy, USA
}

\begin{abstract}
In this paper we examine the impact of forceful or violent environmental sabotage (FVES) on U.S. elections. We argue that voters see ideological similarities between groups that engage in FVES and other nonviolent environmental organizations, like the Green Party. This means that when an environmentalist organization engages in FVES, it has a negative impact on voter attitudes toward all environmental organizations. Moreover, this negative impact will be stronger if environmentalists had previously made electoral progress, and so they cannot use the excuse that democratic methods had failed and they were forced to turn to FVES. We demonstrate this by showing that when FVES occurs, Green Party candidates tend to win a lower share of the vote in the next election. However, this effect is conditional on the prior electoral history of the Green Party. If the Green Party has a poor electoral record, then sabotage has little effect, but if the Green Party has a better electoral record, then voters are less forgiving of sabotage. We find no evidence that FVES effects Republican or Democratic vote shares. We conclude that different organizations within the same social movement are connected in ways that impact electoral outcomes.
\end{abstract}

\section{KEYWORDS}

Eco-sabotage;

environmentalism; ecoterror; election; Green Party; terror; political violence; voting

\section{Introduction}

Environmental activism takes many forms. It can look conventional, like voting for the Green Party; but it can also be contentious, incorporating protests, boycotts, and sometimes even extreme actions like forceful and violent environmental sabotage (hereafter referred to as FVES). The environmental movement is large; it contains a multitude of tactics. ${ }^{1}$ Researchers have long been interested in whether these types of tactics can effectively coexist, or whether they tend to clash with each other. ${ }^{2}$ In this paper we advance that scholarship, by identifying a conditioning factor that determines when these tactical choices prove incompatible. Specifically, we test how prior electoral results determine whether FVES is associated with less subsequent success for the Green Party.

We are informed both by broader theories of political violence, and by the specifics of our case. Some prior research finds that political violence has a positive "radical flank" effect, whereby it boosts the reputation of organizations with similar goals but with different-more conventional-tactics, by making them seem more palatable by comparison. ${ }^{3}$ However, a set of rival theories suggests the reverse: that they are substitutes rather than complements, and that any violence within a movement has a negative "radical flank" effect and tarnishes the reputations of all groups with similar goals. ${ }^{4}$ 
We build on these theories by testing them both, and including a third conditioning factor. We also perform our test in a new context. Beginning in the 1980s, some US environmental activists became frustrated by the slow pace of policy change. ${ }^{5}$ They argued that contentious tactics were now legitimate, because conventional tactics had demonstrably failed. ${ }^{6}$ This argument seems to have had important effects at the aggregate level. Analysis of FVES in this period shows that the failure of conventional environmental politics, as measured by Green Party electoral failure, increased the subsequent frequency of FVES. ${ }^{7}$

Thus, combining prior research with the contextual factors unique to this case, we argue in this paper that a conditional factor will determine which "radical flank" effect applies: namely, the electoral history of Green Party candidates. We expect a positive "radical flank" effect to emerge in congressional districts when FVES is conducted-but only if Green Party candidates have repeatedly run and lost in prior elections. If Green Party candidates are either absent, or have been successful, then we expect a negative "radical flank" effect to emerge following FVES in those districts.

We combine U.S. Congressional election results from the Constituency Level Elections Archive (CLEA) with information on FVES from the Global Terrorism Database (GTD) and data on the electoral history of the US Green Party in state and local elections. ${ }^{8}$ Using the location coordinates provided in GTD, we match FVES events to congressional districts. We find that FVES has a negative effect on Green Party congressional candidates' vote shares, but that if the Green Party has a consistent record of running unsuccessful races in state and local elections, then FVES does not have a detrimental effect. Our findings suggest that FVES has different "radical flank" effects conditional on the electoral history of Green Party candidates.

The paper proceeds as follows. First, we describe FVES in the context of the broader political violence literature and also in the context of the specific US case. We focus on definitions, ${ }^{9}$ and on possible causes, ${ }^{10}$ and then we describe how our research fits into this literature. Second, we lay out our specific hypotheses about why FVES will have positive or negative "radical flank" effects, conditional on prior Green Party election results. Our third section describes our data and analyses. Last, we conclude with implications for future research.

\section{Forceful \& violent environmental sabotage (FVES)}

Environmental sabotage is defined as deliberate acts of property damage, aimed at preventing harm to the natural environment. ${ }^{11}$ Some of these activities are relatively minor, such as graffiti or traffic disruption, but we examine FVES—-such as arson, disabling machinery, or releasing captive animals. ${ }^{12}$ There is an active debate about whether FVES constitutes terrorism. In FVES and other environmental sabotage incidents, nobody has been physically harmed and only $10 \%$ of incidents involve even threats of personal harm. ${ }^{13}$ Often strict precautions were taken against harming living things. ${ }^{14}$ Thus, it can be argued that environmental sabotage should not be labeled as terrorism. ${ }^{15}$ Other arguments against the label focus on the criminalization of dissent ${ }^{16}$ and the purported double-standard whereby organizations that harm the natural environment are not labeled as violent, let alone as terrorist. ${ }^{17} \mathrm{We}$ are interested in a specific subset of environmental sabotage incidents-FVES.

GTD records incidents of "threatened or actual use of illegal force and violence by a nonstate actor to attain a political, economic, religious, or social goal through fear, coercion, or intimidation." ${ }^{18}$ Radical environmentalists perpetrated a subset of these incidents, and those incidents constitute our measure of FVES. ${ }^{19}$ Most FVES incidents are carried out by radical 
environmentalist groups like Earth First!, the Earth Liberation Front (ELF), and the Animal Liberation Front (ALF) that are often analyzed separately from the rest of the environmental movement. ${ }^{20}$ They are more radical, more direct, and more secretive-sometimes operating through individual cells with no explicit links to each other or to other environmental organizations. ${ }^{21}$ Excluding incidents with unknown perpetrators, ${ }^{22}$ as we discuss in our empirical section, leaves us with FVES incidents that are primarily large-scale arson attacks.

Usually researchers have focused on two questions: (1) does environmental sabotage, in general, constitute terrorism or not $^{23}$ and (2) what factors cause environmental sabotage ${ }^{24}$ These two subfields have greatly added to our understanding of environmental sabotage. However, each of them neglects important questions that are addressed by this paper. We ask whether FVES, despite the debate about labeling, has the same electoral effects and consequences that prior research has found for political violence and terrorism. In the next section we show how asking this question helps us contribute to both of the literatures above.

\section{Shared ideology equals shared reputation}

We argue that all organizations in the environmental movement share a joint reputation among voters. ${ }^{25}$ This possibility has not received much attention from academics studying environmental sabotage, let alone FVES. $^{26}$

The environmental movement in the U.S. encompasses a tremendous amount of variety. ${ }^{27}$ There are thousands of different organizations, with millions of different members, and no end to the number of different ideas about what to prioritize and how to prioritize it. ${ }^{28}$ Different groups pursue their goals with different tactics. ${ }^{29}$ Despite this rich variety, ${ }^{30}$ they share an umbrella goal, ${ }^{31}$ a "multilayered collective identity,"32 and a core ideology ${ }^{33}$ making them an organizational field. ${ }^{34}$

Doherty (2002) provides the most comprehensive statement of this idea. His research begins with the motivating question: "Is it justifiable to regard those who visit nature reserves and those who trash branches of McDonalds as being part of the same social movement and sharing the same politics?"35 After surveying the ideological content of different environmental organizations in developed democracies, he finds three common themes: commitment to participatory decision-making, ecological preservation, and social equality. Other scholars have reached the same conclusion about a shared ideological core across radical environmental and-despite some differences-animal rights groups. ${ }^{36}$ Furthermore, although we do not examine this possibility directly in our paper, activists and supporters could transition between groups, objectives, and tactics while remaining in the organizational field. ${ }^{37}$ These links usually remain informal, with institutionalized co-operation relatively rare, but sometimes seemingly disparate groups communicate with one another and can even secretly coordinate activities. ${ }^{38}$

This ideological overlap may have important political consequences. Although most voters are not experts in political ideology ${ }^{39}$ they are aware of the brand names of political organizations. ${ }^{40}$ A positive brand name, created over time by consistent and coordinated actions by members of that organization, can be a considerable electoral asset. Conversely, an organization's brand name can be severely damaged if members' actions prove unpopular. ${ }^{41}$ We extend this idea one more step, suggesting that it might apply to an organizational field as well as to single organizations.

Given that the environmental movement shares one ideology, ${ }^{42}$ we postulate that the actions of one group might effect the reputation of all. This could happen in many ways; 
we highlight the specific role of FVES. ${ }^{43}$ We are not suggesting that the Green Party and radical activist groups coordinate their actions. But there is evidence that activists see a connection. Specifically, we build on evidence that FVES is more likely when conventional tactics have been tried and floundered. ${ }^{44}$ Radical environmentalists seem more likely to engage in FVES if the tactics of their conventional cousins have been found wanting. ${ }^{45}$ We build on this finding by asking whether environmentalists who engage in FVES then make it harder for conventional tactics to succeed.

Not only is this a natural next step given prior research, but this question is also relevant to research on the causes of FVES. This literature is split into three areas. Some scholars have highlighted the psychological motivations of saboteurs ${ }^{46}$ and the role of radicalization. ${ }^{47}$ Other work has emphasized opportunity structures and the availability of symbolic targets. ${ }^{48} \mathrm{~A}$ third strand of research focuses on the role of a specific "deep green" ideology. ${ }^{49}$ Our research tests one observable implication of this third strand of research. If environmental extremists were truly marked out by their "deep green" ideology, then there would be little reason to expect that their actions would effect the reputations of other environmentalists who hold different ideologies. However, we contend that their actions influence each other, because of their shared ideology, ${ }^{50}$ and our evidence is consistent with this argument. This suggests that explanations for the causes of environmental sabotage should focus less on "deep green" ideology and more on other factors, like the political context.

In the next section we describe this argument in more detail. We then review prior research on radical flank effects in US movements, which leads into our argument about the interaction between FVES and Green Party electoral history in the US, where we note parallels to other U.S. social and political movements. We also describe how FVES may have broader impacts, for example on other parties' vote shares.

\section{Electoral effects of FVES in U.S.}

We test whether FVES has a positive or negative radical flank effect. Based on three causal mechanisms that we describe below, we expect the prior electoral history of the Green Party to determine the direction of the effect.

First, FVES makes candidates from environmentalist organizations seem less committed to democratic norms and values. Studies on terrorism regularly find that it is seen as less legitimate in democratic contexts. The political and civil liberties encoded in democracy may make the political environment permissive for terrorism, ${ }^{51}$ and dissatisfaction with democracy may motivate terrorism, ${ }^{52}$ but political rights and competition also enshrine a multitude of alternative avenues for expressing dissent, ${ }^{53}$ which can make the negative reputational consequences for organizations utilizing terrorism overwhelming. These consequences have also been found to carry over to other organizations with the same ideological brand. ${ }^{54}$

Second, after FVES voters may revise their assessment of the competence of environmental candidates downwards. By being associated with groups that resort to violence when confronted with obstacles, environmental candidates may be seen as less suitable for the prosaic and patient work of governing. Niche environmentalist parties have to work disproportionately hard to build a reputation for competence, ${ }^{55}$ and we argue that being associated with FVES can undercut this work.

Third, after FVES, candidates from environmental organizations will be less symbolically attractive. Positive aspects of the party brand become tainted by negative 
connotations. ${ }^{56}$ Voters, regardless of their ideological sympathies, tend to see any association with violence as a negative for a political party. ${ }^{57}$

However, we do not expect that these three mechanisms will apply unconditionally to FVES. By removing the menace of physical harm usually associated with terrorism, FVES may better mobilize citizens' support for environmentalism; promoting the environmentalist agenda as it damages or destroys the target and simultaneously advertises the ideology. ${ }^{58}$ Similar to the strategic logic of terrorism, ${ }^{59}$ radical tactics can revitalize stagnant movements, ${ }^{60}$ increase support for moderate groups' efforts by changing the perceptions of moderates, ${ }^{61}$ and highlighting their ideas. ${ }^{62}$

For example, in the US context, the Civil Rights Era was defined by a large organizational field. A plethora of groups used a plethora of tactics. This variance was significant, because moderate nonviolent groups gained public acceptance as radical, direct-action, militant groups emerged in the organizational field. ${ }^{63}$ Militant ideology and urban riots had a positive radical flank effect leading to both black and white communities increasing their support and funding of moderate organizations. ${ }^{64}$

The US Women's Rights movement followed a similar positive radical flank pattern. Radical women's groups and their tactics helped other groups, such as the National Organization for Women, to appear moderate, which aided in their negotiation and public image/diplomacy efforts. ${ }^{65}$ During the same time period, increasingly radical labor activists revitalized more moderate groups in the labor movement and union membership grew. ${ }^{66}$ Furthermore, the relatively small and fragmented welfare rights movement ${ }^{67}$ is nicely analogous to the environmental movement. Welfare rights activists shifted their tactics in response to changes in political opportunities; institutionalized, or conventional, politics were used when legislative bodies were receptive, but when defeat appeared imminent, activists shifted strategies including alternative third-party support. ${ }^{68}$

Radical flank effects are not restricted to "left" movements. The U.S. white supremacy movement is composed of many groups that may appear similar on the surface, but the groups have various tactics, strategies, and goals. ${ }^{69}$ The organizational field of white supremacy is quite diverse as evidenced by activists' joint membership in patriot-militia groups and other conservative groups, and their routine interactions at conferences and rallies with an assortment of right-wing activists and groups. ${ }^{70}$

Yet when moving beyond a movement-specific analysis, the empirical evidence supporting radical flank effects is rather weak. ${ }^{71}$ In organizational fields consisting of militant groups, the less militant groups did not always enjoy the benefits of a radical flank effect, ${ }^{72}$ but sometimes they did. ${ }^{73}$ Thus, although we began with three causal mechanisms suggesting a negative effect, it is worth considering that FVES could also have a positive "radical flank" effect. We argue that one way out of this debate is to focus on conditioning factors. By isolating the conditions under which "radical flank" effects will be predominantly negative, we can better understand the general phenomena. Green Party prior electoral progress is just such a conditioning factor.

A common argument that radical environmentalists make is that they were forced to turn to radical tactics because all other tactics were unfairly blocked. Frustration with the pace of democratic change was an important factor behind the creation of Earth First!, ${ }^{74}$ as activists felt the government was perennially unresponsive. This frustration also helped inspire specific FVES actions; for example, the arson of the proposed veterinary diagnostic laboratory (VDL) at the University of California, Davis, in 1987: "Following unsuccessful, non-destructive protests by others against the VDL, the Animal Liberators decided that their only option was to burn 
down the laboratory before it was completed." ${ }^{75}$ Prior research has found empirical evidence that frustration with the failure of conventional politics increases the frequency of FVES. ${ }^{76}$ Therefore, when the Green Party has a poor electoral record, one of our causal mechanismsreduced legitimacy - may not apply as strongly. FVES may seem more legitimate if perpetrators can use "last resort" or "unfairly shut out" arguments to buttress their actions. ${ }^{77}$ But, following prior research, we argue that this will not happen immediately. Only if the Green Party has been active in running candidates at the state and local levels, but has been consistently unsuccessful, will the chance of a negative backlash decrease. ${ }^{78}$

This discussion of mechanisms and conditioning factors is summarized in our first hypothesis:

H1: FVES will be associated with lower Green Party vote share in a given Congressional District, unless the Green Party has previously fielded consistently unsuccessful candidates, at the state and local level, in the state containing that Congressional District.

Thus far we have focused on the Green Party since that is the only party that espouses the same core principles as radical environmentalists, ${ }^{79}$ but FVES may have other consequential electoral impacts. It is important to consider other parties because the effects may be easier to detect empirically, given that the Green Party runs relatively few candidates. Thus, although $H 1$ is central, we also explore how FVES may impact other parties. We test two rival hypotheses against each other.

Voters may interpret FVES as a law-and-order or security concern, which is similar to other terrorism and political violence. If so, then we expect Republicans to benefit because they are perceived as strong on these issues. ${ }^{80}$ For example, in the 1960s and 1970s, at the national-level, Americans identified law-and-order as pressing issues during spates of frequent protest violence, and at the county-level, protest violence resulted in disproportionate election results favoring Republicans. ${ }^{81}$ And in the 2002 United States Congressional election, the Republican Party won large gains, in part, due to the September 11th attacks and President Bush's response. $^{82}$ This leads to our second hypothesis:

H2: FVES will be associated with higher Republican congressional vote shares in a given Congressional District, even when the Green Party has previously fielded consistently unsuccessful candidates, at the state and local level, in the state containing that Congressional District.

But FVES may not prime law-and-order or security concerns because FVES explicitly avoids human casualties. By removing citizens' physical threat from the equation, FVES may not encourage voters to become more conservative ${ }^{83}$ or more polarized. ${ }^{84}$

Other findings suggest terrorism shifts electorates' preferences to the left. Voters can become more willing to make small concessions - alongside demanding stronger security to limit future threats. ${ }^{85}$ If this effect holds in response to FVES in the United States, then this means that not only may the Green Party gain votes, but the Democrats may also benefit. Since the 1980s and the erosion of environmental protection, the Democratic Party has enjoyed the reputation of being the pro-environment major party ${ }^{86}$ and thus the benefit to the Democrats may be actually larger because they share less ideologically with the Green Party or environmental extremists and so will not be tainted by negative radical flank effects. This leads us to our third hypothesis: 
H3: FVES will be associated with higher Democratic congressional vote shares in a given Congressional District, even when the Green Party has previously fielded consistently unsuccessful candidates, at the state and local level, in the state containing that Congressional District.

Radical environmentalists' tactics have been influenced by other movements' strategic decisions and contentious politics, particularly by European nationalists' direct action and political violence. ${ }^{87}$ There may be parallel electoral effects between nationalist terrorism and FVES. Even though these are different contexts, it helps elucidate and specify the reputational consequences of FVES we described. ${ }^{88}$ After terrorism, some civilians become hostile toward perpetrators of violence and support hardline, aggressive responses and security. ${ }^{89}$

Terror attacks also tend to reduce support for organizations ideologically associated with the perpetrators. ${ }^{90}$ In Spain when the armed organization ETA and the associated political party Batasuna both represented the Basque nationalist movement, incidents of ETA violence frequently decreased Batasuna's vote share. ${ }^{91}$ In Northern Ireland, when the Provisional IRA decreased the frequency of terror attacks during election years, it had a positive effect on Sinn Féin's vote share. ${ }^{92}$

Terrorism's power to manipulate citizens lies in the ability to conjure fear for personal safety, ${ }^{93}$ stimulating voters' anxiety and fear. This negative connotation will lead to decreased vote share for any party associated with extra-legal action. ${ }^{94}$ The first consequence of increased support for right-wing security policies is unlikely to apply, but the second consequence, of electoral backlash against groups associated with perpetrators, is likely to apply. These differences emerge because FVES explicitly avoids human casualties.

\section{Research design \& analysis}

To test our hypotheses, we use panel data where the U.S. congressional race-election year is the unit of analysis. Each observation represents one of the 435 regular Congressional races that occur every second November. Our first dependent variable is Green Vote Share: the percentage of votes won by the Green Party candidate. Data come from the Constituency Level Election Archive (CLEA) over a twenty-eight-year period from 1984 to 2012.95 Unsurprisingly, for around 95\% of our observations, this variable takes on a value of zero; in the 6,525 regular November elections from 1984 to 2012, the Green Party candidate vote share was zero in all but 330 races and their maximum vote share was $10.11 \% .{ }^{96}$ This lack of variation means we must be careful about out-of-sample extrapolation, but it should not bias our estimates as it only makes it more difficult for us to find support for our first hypothesis. CLEA is also our source for two other dependent variables: Republican Vote Share and Democratic Vote Share. Concerns about lack of variation in these dependent variables do not apply.

To test our first hypothesis, we analyze electoral districts where the Green Party fielded a congressional candidate at time $t$ - 1 . Some districts experienced FVES between $t-1$ and $t$, whereas other districts did not. We examine how Green Party vote share changed between $t-1$ and $t$ in these districts conditional on FVES events. To isolate these districts, we take districts that had not been redistricted since $t-1$ and had a Green Party vote share greater than zero at $t$-1. Excluding other districts from the analysis ensures that FVES effects are not overwhelmed by the sheer frequency of districts where the Green Party never runs a congressional candidate. The Green Vote Share dependent variable consequently ranges from $0-4.11 \%$. 
Our key independent variable, Twenty-Four Month FVES, comes from GTD. We only include events with an environmental motivation by matching the names of perpetrators against the Terrorism Research and Analysis Consortium (TRAC) environmentalist category. From 1984-2012, ALF and ELF perpetrated roughly 80\% of the 154 FVES incidents in our sample. We count the number of FVES incidents by identified groups/actors since the last Congressional election (i.e. over the last twenty-four months): it ranges from zero to four. ${ }^{97}$ Although we do not account for variation in attack severity, GTD's coding enhances comparability of incidents by only including FVES.

Our other most important variables are our measures of prior Green Party electoral progress: Five-Year State Candidates, and Percent State Failure. Five-Year State Candidates measures the number of Green Party candidates who ran for State House, State Senate, or other state-wide office, over the last five years. It is measured per state, so will be identical for all districts in a state. ${ }^{98}$ Percent State Failure is the percentage of these candidates who did not win. If the Green Party fielded no candidates, then this is coded as $0 \%$. Thus, higher values on this variable represent states only where the Green Party has fielded candidates who lost, not states where the Green Party has not fielded candidates. ${ }^{99}$ This is our central measure of Green Party prior electoral progress, so we multiplicatively interact Percent State Failure with Twenty-Four Month FVES. This tests whether FVES generates less backlash if persistent Green Party failure has created frustration with democratic methods.

We control for overall levels of party support using a one-election cycle lagged dependent variable, e.g. Green Vote Share $_{(t-1)}$, Democratic Vote Share $(t-1)$ or Republican Vote Share $_{(t-1)}$. We also include a Year counter, and a Presidential Year indicator to help control for turnout changes $^{100}$ and for potential trends in environmentalism and electoral politics over time. Democratic Incumbent is a dichotomous variable for Democratic incumbency, and Republican Incumbent does the same for Republicans. ${ }^{101}$ Descriptive statistics are provided in Table 1.

Although GTD and CLEA data cover the entire period of 1984-2012, our Five-Year State Candidates measure begins counting candidates in 1984, meaning that the first nonmissing values of the variable are in 1989, and the data collection ends in 2005, reducing the number of observations we can include in our regressions. Other important points from Table 1 are the low average values of Green Party vote share, as already discussed, and the slightly higher average values on the Democratic incumbent variable than the Republican incumbent variable, which comports with the slightly higher average value of Democratic vote share than Republican vote share.

There are three important points about our design. First, we only model the effect that FVES has on voters in the district where the incident occurred. This is a restrictive assumption that ignores possible indirect effects. ${ }^{102}$ However, FVES limits collateral damage, so we think the effects are likely concentrated. Future research could examine spillover, however. Second, we focus on the Green Party as the primary electoral vehicle for environmentalism: it is the electoral history of the Green Party that we use as a conditioning independent variable, and it is the Green Party congressional results that we use as a dependent variable. We do test whether FVES effects the vote shares of other parties, but we do not include the possibility that the election of pro-environment candidates from other parties plays a similar conditioning role as would the election of Green Party candidates. Although center-left parties, such as the Democrats in the U.S., are sometimes seen as the party of environmental protection and may run pro-environment candidates, these parties were not founded on ecological ideology in the same way that radical environmental groups and Green parties both were (Doherty 2002). 
Table 1. Descriptive statistics.

\begin{tabular}{lrrrcc}
\hline & & & Std. & \\
Variable & $\mathrm{N}$ & Mean & Dev. & Min. & Max. \\
\hline Dependent Variables & & & & & \\
Green Vote Share & 6525 & 0.038 & 0.292 & 0 & 10.114 \\
Democratic Vote Share & 5998 & 18.752 & 10.443 & 1.130 & 100 \\
Republican Vote Share & 5906 & 17.401 & 10.504 & 0.231 & 100 \\
Independent Variables & & & & & \\
Twenty-Four Month Environmental Sabotage & 6525 & 0.024 & 0.197 & 0 & 4 \\
Percent State Failure & 3480 & 34.142 & 46.044 & 0 & 100 \\
Interaction: Twenty-Four Month Environmental Sabotage * Percent State & 3480 & 2.080 & 17.854 & 0 & 315.152 \\
$\quad$ Failure & & & & & \\
Control Variables & & & & & \\
Percent State Failure & 3480 & 3.936 & 9.285 & 0 & 64 \\
Democratic Incumbent & 6525 & 0.483 & 0.500 & 0 & 1 \\
Republican Incumbent & 6525 & 0.413 & 0.492 & 0 & 1 \\
Year & 6525 & 1998 & 8.642 & 1984 & 2012 \\
Presidential Year & 6525 & 0.533 & 0.499 & 0 & 1 \\
\hline
\end{tabular}

Thus we focus on the Green Party in our analysis. Third, testing our hypotheses allows us to gauge whether the empirical evidence is consistent with our argument, but we cannot definitively rule out alternative explanations. For example, media coverage may be greater for some FVES incidents than others, or voters may be motivated in ways that are not captured in our theory, or a variety of other processes may be at play. This is an inevitable consequence of non-experimental research, and so although we control for as many features as possible, it will be important for future work to explore voter reactions to FVES in more detail. We take a first step.

As previously described, hypothesis 1 (Green Party Vote Share) is tested using the subsample of congressional districts with a Green Party candidate at time $t$ - 1 , which restricts the number of observations for the first regression to less than one hundred. ${ }^{103}$ It also causes Twenty-Four Month FVES to assume a binary distribution; none of these districts experienced more than 1 incident between elections. In the Democratic and Republican vote share models, there is more variation in the measure so it maintains a count distribution.

It also means the specification is more vulnerable to the possibility of an endogeneity effect. That is, perhaps it is the expectation of a decline in congressional vote share that motivates FVES, rather than FVES occurring and then leading to a decline in congressional vote share. Or perhaps FVES is a qualitatively different phenomena in districts where the Green Party ran a congressional candidate in the last election, and so perhaps it is this context, more than the FVES itself driving the results. Although endogeneity problems are always a real danger in non-experimental research, ${ }^{104}$ a variety of factors support the credibility of our specification, despite the specter of such problems. For example, FVES does not differ in frequency, severity, or target type, based on the last Green Party congressional race results. ${ }^{105}$ This does not mean that endogeneity is not a problem, it simply means that frustration with the electoral process likely takes years to develop ${ }^{106}$ and so limiting our analysis to races where the Green Party fielded a congressional candidate in the last election cycle is unlikely to bias our estimates.

We use a multilevel regression ${ }^{107}$ to test our hypotheses because congressional districtelection year is our unit of analysis and so each congressional district may harbor its own eccentricities. The multilevel framework estimates a different intercept value for each district, helping account for factors not explicitly measured in our control variables. Our first model is a multilevel linear regression predicting Green Vote Share on the basis of 
prior green party vote share, incidents of FVES, and their interaction-alongside a battery of controls. We report the results in Table 2 below.

Rather than dwelling on the coefficients, we generate predicted values to interpret the regression. ${ }^{108}$ Consider a hypothetical congressional election in 2010, in a district where the Green Party won $2.5 \%$ of the vote in 2008. Assume also that there is a Republican incumbent, and that the district is located in a state where the Green Party ran four candidates for state-level offices over the past five years. These assumptions are equivalent to setting each variable to its mean or mode, and thus creating an "average" district. ${ }^{109}$ Then, we create clones of this average district, each with a slightly different value of our independent variables of interest: Green Party electoral history and FVES, and look at how the predicted value of the dependent variable changes.

First, we consider the version of the average district that has the lowest value of "failure percentage." If all four state-level candidates in the last five years won their races, then, if there are no FVES incidents between $t-1$ and $t$, Green Vote Share is predicted to decline from $2.5 \%$ to $1.62 \%$ (with a $95 \%$ confidence interval of $1.32 \%$ to $2.50 \%$ ). This is an intuitively plausible result given the Green Party's generally poor record. However, if an FVES incident were to occur in such a district, the predictions of the model are dramatically different. Now, the decline in Green Party vote share is predicted to be much steeper, going to $-2.69 \%$ (with a 95\% confidence interval ranging from $-2.98 \%$ to $-1.84 \%$ ). Although negative vote share is clearly implausible, it is an artifact of combining a linear specification with a dependent variable being clustered close to zero. ${ }^{110}$

Second, we can examine whether FVES has this same dramatic effect if all four of their state-level candidates had failed to win. Then, zero FVES incidents would lead to a decline in vote share to $1.67 \%(1.37 \%-2.55 \%)$, and one incident would lead to a decline in vote share to $2.28 \%$ (1.99\%-3.16\%). Thus we find strong support for H1. There is a tangible voter backlash against the Green Party if FVES occurs after the Green Party has previously been successful in state-level elections. If the Green Party has no record of electoral progress, then this backlash is indistinguishable from zero.

Having found support for $H 1$, we now test $H 2$ and $H 3$ regarding whether the interaction between FVES and Green Party performance effects the vote shares of other parties. Table 3 presents two models, testing H2 (Republican vote share) and H3 (Democratic vote share).

The coefficients of interest here ${ }^{111}$ suggest on their face that if the percent state failure is zero, then FVES has no effect on either party. For a more thorough interpretation, we set the control variables to their means or modes-a lagged vote share of $40 \%$, and a Republican incumbent-and generate predicted values of major parties' vote shares. Table 4 compares election scenarios in which over the past five years the Green Party ran

Table 2. The impact of environmental sabotage on green vote share.

\begin{tabular}{lc}
\hline Variable & Model 1: Baseline \\
\hline Twenty-Four Month Environmental Sabotage & $-4.304^{* * *}(0.019)$ \\
Interaction: Twenty-Four Month Environmental Sabotage * Percent State Failure & $0.049^{* *}(0.022)$ \\
Green Vote Share $(\mathrm{t}-1)$ & $0.150^{*}(0.074)$ \\
Democratic Incumbent & $0.017(0.263)$ \\
Republican Incumbent & $0.113(0.259)$ \\
Five-Year State Candidates & $-0.001(0.004)$ \\
Percent State Failure & $0.001(0.003)$ \\
Year & $0.003(0.024)$ \\
Presidential Year & $-0.135(0.202)$ \\
Constant & $-6.386(48.643)$ \\
Observations & $85(75$ groups) \\
Group Standard Deviation & 0.360 \\
\hline
\end{tabular}


Table 3. Environmental sabotage \& impact on republican \& democratic vote share.

\begin{tabular}{lcc}
\hline Variable & $\begin{array}{c}\text { Model 2: } \\
\text { Republicans }\end{array}$ & Model 3: Democrats \\
\hline Twenty-Four Month Environmental Sabotage & $-1.474(1.125)$ & $-1.711(1.113)$ \\
Interaction: Twenty-Four Month Environmental Sabotage * Percent State & $0.013(0.015)$ & $0.023(0.014)$ \\
$\quad$ Failure & & \\
Lagged Vote Share $(\mathrm{t}-1)$ & $0.503^{* * *}(0.019)$ & $0.426^{* * *}(0.019)$ \\
Five-Year State Candidates & $-0.030(0.019)$ & $-0.022(0.019)$ \\
Percent State Failure & $0.011^{* * *}(0.004)$ & $-0.006(0.004)$ \\
Year & $0.341^{* * *}(0.051)$ & $0.210^{* * *}(0.053)$ \\
Presidential Year & $-5.917^{* * *}(0.402)$ & $-3.658^{* * *}(0.409)$ \\
Democratic Incumbent & $-1.132^{* *}(0.536)$ & $5.896^{* * *}(0.550)$ \\
Republican Incumbent & $4.865^{* * *}(0.528)$ & $-0.897(0.564)$ \\
Constant & $-671.067^{* * *}$ & $-410.372^{* * *}$ \\
& $(101.153)$ & $(105.427)$ \\
Observations & $2,154(1,104$ groups) & $2,160(1,112$ groups $)$ \\
Group Standard Deviation & 0.0000004 & 1.658 \\
\hline
\end{tabular}

Table 4. Election scenarios \& predicted impact on vote share.

\begin{tabular}{lcc}
\hline Predicted vote share & Republicans & Democrats \\
\hline If no sabotage events and state-level GP failure 0\% & $39.64 \%(34.64 \%-53.37 \%)$ & $28.59 \%(23.85 \%-42.57 \%)$ \\
If one sabotage event and state-level GP failure 0\% & $38.18 \%(33.66 \%-51.70 \%)$ & $26.90 \%(22.30 \%-40.27 \%)$ \\
If no sabotage events and state-level GP failure 100\% & $38.51 \%(33.86 \%-52.06 \%)$ & $27.73 \%(23.05 \%-41.68 \%)$ \\
If one sabotage event and state-level GP failure 100\% & $38.29 \%(33.47 \%-52.23 \%)$ & $28.55 \%(23.88 \%-42.46 \%)$ \\
\hline
\end{tabular}

state and local candidates without winning ( $100 \%$ failure) to when they won ( $0 \%$ failure) and find that FVES has no meaningful effect on major parties' vote shares regardless of the Green Party's electoral history. H2 and H3 are not supported.

Overall, these models suggest that FVES does have important electoral consequences. Even though radical environmentalist groups and the Green Party are not directly affiliated, it appears that voters identify an ideological association between these two distinct wings of environmentalist politics. Voters react to FVES by punishing the Green Party at the next election-unless the Green Party has the excuse that democratic methods have been tried and have failed. The data show that Green Party candidates are already at a disadvantage from one election to the next, but FVES makes this significantly worse. In terms of other effects, FVES does not seem to prime voters to consider security in ways that would lead them toward Republicans, nor are they primed to consider environmentalism in ways that might lead them toward Democrats.

\section{Conclusion}

Two particularly important conclusions can be drawn from this research. First, our findings on the effects of FVES change with the electoral context. This suggests that the perceived legitimacy of violent direct action does not just depend on the level of democracy in a country, but also on whether democratic channels seem to have been tried and failed. If these channels are working, or if they have not been tried, then FVES reduces Green Party vote shares by convincing some voters to not vote for the Green Party or to sit out the election. But if people feel abandoned or ignored by conventional channels, then they may also feel that political violence is the only way left to engage in the political system. ${ }^{112}$ 
Second, FVES does not appear to prime voters on law-and-order or security issues, which is significantly different than the effect of terrorism. This suggests that not only do some academics see important differences between FVES and terrorism, ${ }^{113}$ but voters see significant differences too.

Most political ideologies spread by having not one, but many organizational offspring. From a single ideology may spring forth charities, interest groups, political parties, and even terrorist cells. These organizations are all part of the same social movement, but they differ in their preferred tactics, their relationship with the state, and many other organizational characteristics. ${ }^{114}$ This diverse family may work together in close coalitions, or alternatively they may completely refuse to associate with one another. But voters may perceive connections between them, the media may cover connections between them, and relationships of substitution or complementation may emerge from these connections. Thus, in order to understand organizational activities, from election campaigns to political violence, it is important to examine the nature of these connections. This paper is a step in that important direction.

\section{Acknowledgments}

The authors gratefully acknowledge helpful comments from the Editor and anonymous reviewers. Professor Farrer also wishes to thank the staff at Sanctuary in Iowa City for their good humor and kindness during the writing of this article.

\section{Disclosure statement}

No potential conflict of interest was reported by the authors.

\section{ORCID}

Ben Farrer (1) http://orcid.org/0000-0002-5889-5498

Graig R. Klein (i) http://orcid.org/0000-0002-1745-6712

\section{Notes}

1. Jason P. Matzke, "On Compromise in Radical Environmental Activism," Malgorzata Dereniowska 24, (2018): 9-38.

2. Thad Dunning, "Fighting and Voting: Violent Conflict and Electoral Politics," Journal of Conflict Resolution 55, no. 3 (2011): 327-339.

3. Richard C. Fording, "The Conditional Effect of Violence as a Political Tactic: Mass Insurgency, Welfare Generosity, and Electoral Context in the American States," American Journal of Political Science 41, no. 1 (1997): 1-29; William A. Gamson, The Strategy of Social Protest (Belmont, CA: Wadsworth, 1990); Herbert H. Haines, "Black Radicalization and the Funding of Civil Rights: 1957-1970," Social Problems 32, no. 1 (1984): 31-43; Herbert H. Haines, Black Radicals and the Civil Rights Mainstream, 1954-1970 (Knoxville: University of Tennessee Press, 1988); Hanspeter Kriesi, Ruud Koopmans, Jan Willem Duyvendak, and Marco G. Giugni, eds., New Social Movements in Western Europe: A Comparative Analysis (Minneapolis: University of Minnesota Press, 1995); Aila M. Matanock and Paul Staniland, "How and Why Armed Groups Participate in Elections," Perspectives on Politics 16, no. 3 (2017): 710-727; Doug McAdam, John D. McCarthy, and Mayer N. Zald, eds., Comparative Perspectives on Social Movements (Cambridge, UK: Cambridge University Press, 1996); Omar Wasow, "Do Protests Matter? Evidence from the 1960s Black Insurgency," (2017), http://www.omarwasow.com/ 
Protests_on_Voting.pdf; Michael Weintraub, Juan F. Vargas, and Thomas E. Flores, "Vote Choice and Legacies of Violence: Evidence from the 2014 Colombian Presidential Elections," Research and Politics 2, no. 2 (2015): 1-8.

4. Erica Chenoweth and Kurt Schock, "Do Contemporaneous Armed Challenges Affect The Outcomes Of Mass Nonviolent Campaigns?” Mobilization: An International Quarterly 2, no. 4 (2015): 427-51; Benjamin Farrer and Graig R. Klein, "The Political Roots of Domestic Environmental Terrorism," Journal of Elections, Public Opinions, and Parties 27, no. 2 (2017): 133-155; Ruud Koopmans, Democracy from Below: New Social Movements and the Political System in West Germany (Boulder, CO: Westview, 1995).

5. Koopmans, Democracy from Below, 17 (see note 4).

6. Dean Kuipers, Operation Bite Back: Ron Coronado's War To Save The American Wilderness (New York: Bloomsbury, 2009); Peter C. List, ed., Radical Environmentalism: Philosophy and Tactics (Belmont: Wadsworth, 1993); Rik Scarce, Eco-Warriors: Understanding the Radical Environmental Movement, 2nd ed. (Walnut Creek, CA: Left Coast Press, 2006).

7. Farrer and Klein, "The Political Roots of Domestic Environmental Terrorism"(see note 4).

8. Farrer and Klein, "The Political Roots of Domestic Environmental Terrorism" (see note 4); Ken Kollman, Allen Hicken, Daniele Caramani, David Backer, and David Lublin, "Constituency-Level Elections Archive," Produced and distributed by Ann Arbor, MI: Center for Political Studies, University of Michigan ([dataset], 2017); START, "Global Terrorism Database." https://www.start.umd.edu/gtd/

9. Randall Amster, "Perspectives on Ecoterrorism: Catalysts, Conflations, and Casualties," Contemporary Justice Review 9, no. 3 (2006): 287-301; Sivan Hirsch-Hoefler and Cas Mudde, “Ecoterrorism': Terrorist Threat or Political Ploy?" Studies in Conflict \& Terrorism 37, no. 7 (2014): 586-603.

10. Nick Deshpande and Howard Ernst, Countering Eco-Terrorism in the United States: The Case of "Operation Backfire" (College Park, MD: National Consortium for the Study of Terrorism and Responses to Terrorism [dataset], 2012); Jennifer Varriale Carson, Gary LaFree, and Laura Dugan, "Terrorist and Non-Terrorist Criminal Attacks by Radical Environmental and Animal Rights Groups in the United States, 1970-2007," Terrorism and Political Violence 24, no. 2 (2012): 295-319.

11. Amster, "Perspectives on Ecoterrorism" (see note 9); Deshpande and Ernst, Countering EcoTerrorism in the United States (see note 10); Hirsch-Hoefler and Mudde, "Ecoterrorism" (see note 9); Kuipers, Operation Bite Back (see note 6); Paul Joosse, "Leaderless Resistance and Ideological Inclusion: The Case of the Earth Liberation Front," Terrorism and Political Violence 19, no. 3 (2007): 351-68; List, Radical Environmentalism (see note 6); Lyle Munro, "Strategies, Action Repertoires and DIY Activism in the Animal Rights Movement," Social Movement Studies 4, no. 1 (2005): 75-94; David Naguib Pellow, Total Liberation: The Power and Promise of Animal Rights and the Radical Earth Movement (Minneapolis: University of Minnesota Press, 2014); Scarce, Eco-Warriors (see note 6).

12. GTD records violent environmentalism events making it a suitable theoretical and methodological data source for our empirical analysis.

13. Hirsch-Hoefler and Mudde, "Ecoterrorism" (see note 9).

14. Deshpande and Ernst, "Countering Eco-Terrorism in the United States" (see note 10).

15. Hirsch-Hoefler and Mudde, "Ecoterrorism" (see note 9); List, Radical Environmentalism (see note 6); Varriale Carson et al., "Terrorist and Non-Terrorist Criminal Attacks by Radical Environmental and Animal Rights Groups in the United States, 1970-2007" (see note 10).

16. Gary Ackerman, "Beyond Arson? A Threat Assessment of the Earth Liberation Front," Terrorism and Political Violence 15, no. 4 (2003): 143-70; Amster, "Perspectives on Ecoterrorism" (see note 9); Michael Loadenthal “Eco-Terrorism': An Incident-Driven History of Attack (1973-2010)" Journal for the Study of Radicalism 11, no. 2 (2017): 1-33; DeMond Shondell Miller, Jason David Rivera, and Joel C. Yelin, "Civil Liberties: The Line Dividing Environmental Protest and Ecoterrorists" Journal for the Study of Radicalism 2, no. 1 (2008): 109-23. 
17. Pellow, Total Liberation (see note 11); Scarce, Eco-Warriors (see note 6); Steve Vanderheiden, "Eco-terrorism or Justified Resistance? Radical Environmentalism and the 'War on Terror'," Politics and Society 33, no. 3 (2005): 425-47. Steve Vanderheiden "Radical Environmentalism in an Age of Antiterrorism" Environmental Politics 17, no. 2 (2008): 299-318.

18. START, "Global Terrorism Database" (see note 8).

19. Hirsch-Hoefler and Mudde, "Ecoterrorism" (see note 9); Loadenthal, "Eco-Terrorism" (see note 17); Varriale Carson et al., "Terrorist and Non-Terrorist Criminal Attacks by Radical Environmental and Animal Rights Groups in the United States, 1970-2007" (see note 10).

20. Russell J. Dalton, The Green Rainbow: Environmental Groups in Western Europe (New Haven: Yale University Press, 1994).

21. Deshpande and Ernst, "Countering Eco-Terrorism in the United States" (see note 10); Sean P. Eagen, "From Spikes to Bombs: The Rise of Eco-Terrorism," Studies in Conflict and Terrorism 19, no. 1 (1996): 1-18; Joosse, "Leaderless Resistance and Ideological Inclusion (see note 11); Kuipers, Operation Bite Back (see note 6); List, Radical Environmentalism (see note 6); Scarce, Eco-Warriors (see note 6).

22. A high percentage of GTD events are unattributed to a group or individual and are still included in event-level analyses. Group-level analyses drop the unattributed events, recognizing the results are based on a sample of all possible events, which is in-line with our analysis; in an imperfect data world, especially with regard to the secretive and illegal nature of terrorism, dropping unattributed events is acceptable.

23. Amster, "Perspectives on Ecoterrorism" (see note 9); Hirsch-Hoefler and Mudde, "Ecoterrorism" (see note 9); List, Radical Environmentalism (see note 6); Munro, "Strategies, Action Repertoires and DIY Activism in the Animal Rights Movement" (see note 11).

24. Deshpande and Ernst, "Countering Eco-Terrorism in the United States" (see note 10); Eagen, "From Spikes to Bombs" (see note 21); Jeff Gruenewald, Kayla Allison-Gruenewald, and Brent R. Klein, "Assessing the Attractiveness and Vulnerability of Eco-Terrorism Targets: A Situational Crime Prevention Approach," Studies in Conflict \& Terrorism 38, no. 6 (2015): 433-55; Kuipers, Operation Bite Back (see note 6); Joosse, "Leaderless Resistance and Ideological Inclusion (see note 11); Pellow, Total Liberation (see note 11); Scarce, Eco-Warriors (see note 6); Varriale Carson et al., "Terrorist and Non-Terrorist Criminal Attacks by Radical Environmental and Animal Rights Groups in the United States, 1970-2007" (see note 10).

25. Brian Doherty, Ideas and Actions in the Green Movement (London: Routledge, 2002).

26. Bonnie Meguid, Party Competition between Unequals: Strategies and Electoral Fortunes in Western Europe (Cambridge: Cambridge University Press, 2008).

27. Matzke, "On Compromise in Radical Environmental Activism" (see note 1); David Schlosberg, "Ecological Justice for the Anthropocene," (75-89) in Political Animals and Animal Politics, Marcel Wissenburg and David Schlosberg (Basingstoke, UK: Palgrave Macmillan, 2014), 75-89.

28. Robert Brulle, Agency, Democracy and Nature: The U.S. Environmental Movement from a Critical Theory Perspective (Cambridge, MA: MIT Press, 2000).

29. Environmentalists' tactics include, and have shifted between, mainstream activism, protests and marches, judicial challenges, legislative and electoral politics, civil disobedience, lobbying and public relations campaigns, monkeywrenching, eco-sabotage, and FVES (Matzke, "On Compromise in Radical Environmental Activism" (see note 1); Erik W. Johnson, Jon Agnone, and John D. McCarthy, "Movement Organizations, Synergistic Tactics and Environmental Public Policy," Social Forces 88, no. 5 (2010): 2267-92.

30. Christopher Roote, "Environmental Movements," in The Blackwell Companion to Social Movements (Malden, MA: Blackwell Publishing LTD, 2004).

31. Viviana Asara, "The Indignados as a Socioenvironmental Movement. Framing the Crisis and Democracy," Environmental Policy and Governance 26, no. 6 (2016): 527-42; Sandra R. Levitsky, "Niche Activism: Constructing a Unified Movement Identity in a Heterogeneous Organizational Field," Mobilization: An International Quarterly Review 12, no. 3 (2007): 271-86; Elizabeth S. Clemens and Debra C. Minkoff, "Beyond the Iron 
Law: Rethinking the Place of Organizations in Social Movement Research," The Blackwell Companion to Social Movements, (Malden, MA: Blackwell Publishing LTD, 2004); Bert Fraussen and Darren Halpin, "Political Parties and Interest Organizations at the Crossroads: Perspectives on the Transformation of Political Organizations," Political Studies Review 16, no. 1 (2018) 25-37; Richard W. Scott, "Reflections on a HalfCentury of Organizational Sociology," Annual Review of Sociology 3 (2004): 1-21; Dieter Rucht, "Movement Allies, Adversaries, and Third Parties," The Blackwell Companion to Social Movements, edited by David A. Snow, Sarah A. Soule, and Hanspeter Kriesi (Malden, MA: Blackwell Publishing LTD, 2004); Todd Schifeling and Andrew J. Hoffman, "Bill McKibben's Influence on U.S. Climate Change Discourse: Shifting Field-Level Debates Through Radical Flank Effects," Organization \& Environment (2007): 1-21.

32. Dieter Rucht, "Movement Allies, Adversaries, and Third Parties" (see note 31).

33. Doherty, Ideas and Actions in the Green Movement (see note 25).

34. Clemens and Minkoff, "Beyond the Iron Law" (see note 31).

35. Doherty, Ideas and Actions in the Green Movement, 7 (see note 25).

36. Ackerman, "Beyond Arson?" (see note 17); List, Radical Environmentalism (see note 6); Munro, "Strategies, Action Repertoires and DIY Activism in the Animal Rights Movement" (see note 11).

37. Clemens and Minkoff, "Beyond the Iron Law" (see note 31).

38. Matzke, "On Compromise in Radical Environmental Activism" (see note 1).

39. James Adams, Lawrence Ezrow, and Zeynep Somer-Topcu, "Is Anybody Listening? Evidence That Voters Do Not Respond to European Parties' Policy Statements During Elections," American Journal of Political Science 55, no. 2 (2011): 370-82; John Zaller, The Nature and Origins of Mass Opinion (Cambridge: Cambridge University Press, 1992).

40. Ian Budge and D.J. Farlie, Explaining and Predicting Elections: Issues Effects and Party Strategies in Twenty-Three Democracies (London: George, Allen and Urwin, 1983); Gary W. Cox and Matthew D. McCubbins, Legislative Leviathan, 2nd ed., (Cambridge UK: Cambridge University Press, 2007); Patrick J. Egan, Partisan Priorities: How Issue Ownership Drives and Distorts American Politics (Cambridge: Cambridge University Press, 2013); Donald P. Green, Bradley Palmquist, and Eric Schickler, Partisan Hearts and Minds: Political Parties and the Social Identity of Voters (New Haven: Yale University Press, 2003); James Adams, Lawrence Ezrow, and Debra Leiter, "Partisan Sorting and Niche Parties in Europe" West European Politics 35, no. 6 (2012): 1272-94; Stefaan Walgrave, Anke Tresch, and Jonas Lefevre, "The Conceptualisation and Measurement of Issue Ownership" West European Politics 38, no. 4 (2015): 778-96.

41. Budge and Farlie, Explaining and Predicting Elections (see note 40); Adams et al., "Partisan Sorting and Niche Parties in Europe" (see note 40); Walgrave et al., "The Conceptualisation and Measurement of Issue Ownership" (see note 40).

42. Doherty, Ideas and Actions in the Green Movement (see note 25).

43. Matzke, "On Compromise in Radical Environmental Activism" (see note 1); Levitsky, "Niche Activism" (see note 31).

44. Farrer and Klein, "The Political Roots of Domestic Environmental Terrorism" (see note 4)

45. Farrer and Klein, "The Political Roots of Domestic Environmental Terrorism" (see note 4).

46. Eagen, "From Spikes to Bombs" (see note 21).

47. Donald P. Green, Laurence H. McFalls, and Jennifer K. Smith, "Hate Crime: An Emergent Research Agenda," Annual Review of Sociology 27, no. 1 (2001): 479-504.

48. Gruenewald et al., "Assessing the Attractiveness and Vulnerability of Eco-Terrorism Targets" (see note 24). However, it is important to note that their research design selects on the dependent variable and so cannot be used to make inferences about why particular targets are chosen over others (Scott Ashworth, Joshua D. Clinton, Adam Meirowitz, and Kristopher W. Ramsay, "Design, Inference, and the Strategic Logic of Suicide Terrorism," American Political Science Review 102, no. 2 (2008): 269-73). 
49. Kuipers, Operation Bite Back (see note 6); Arne Naess, "The Shallow and the Deep, LongRange Ecology Movement. A summary," Inquiry 16, no. 1-4 (1973): 95-100; Pellow, Total Liberation (see note 11); Scarce, Eco-Warriors (see note 6).

50. Doherty, Ideas and Actions in the Green Movement (see note 25); List, Radical Environmentalism (see note 6); Pellow, Total Liberation (see note 11); Alexandra Plows, Derek Wall, and Brian Doherty, "Covert Repertoires: ecotage in the UK," Social Movement Studies 3, no. 2 (2004): 199-219; Scarce, Eco-Warriors (see note 6).

51. William L. Eubank and Leonard Weinberg, "Does Democracy Encourage Terrorism?" Terrorism and Political Violence 6, no. 4 (1994): 417-63.

52. Erica Chenoweth, "Democratic Competition and Terrorist Activity," Journal of Politics 72, no. 1 (2010): 16-30.

53. Joel Eyerman, "Terrorism and Democratic States: Soft Targets or Accessible Systems," International Interactions 24, no. 2 (1998): 151-70; Quan Li, "Does Democracy Promote or Reduce Transnational Terrorist Incidents?" Journal of Conflict Resolution 49, no. 2 (2005): 278-97; Alex Schmid, "Terrorism and Democracy," Terrorism and Political Violence 7, no. 4 (1992): 1-19.

54. Eric Bleich and Francesca Lambert, "Why Are Racist Associations Free in Some States and Banned in Others? Evidence from 10 Liberal Democracies," West European Politics 36, no. 1 (2013): 122-49.

55. Farrer and Klein, "The Political Roots of Domestic Environmental Terrorism" (see note 4); Howie Hawkins, Independent Politics: The Green Party Strategy Debate (Chicago: Haymarket Books, 2006).

56. This outweighs "outbidding" consequences whereby the most radical organizations will attract the most support (Donald Horowitz, Ethnic Groups in Conflict, 2nd ed. (Berkeley: UC Press, 2000).

57. Stephan McGrath and Paul Gill, "An Exploratory Study on the Impact of Electoral Participation Upon a Terrorist Group's Use of Violence in a Given Year," Perspectives on Terrorism 8, no. 4 (2014): 27-35; Luis de la Calle and Ignacio Sánchez-Cuenca, "Killing and Voting in the Basque Country: An Exploration of the Electoral Link Between ETA and Its Political Branch," Terrorism and Political Violence 25 (2013): 94-112.

58. Alex Braithwaite, Dennis M. Foster, and David A. Sobek, "Ballots, Bargains, and Bombs: Terrorist Targeting of Spoiler Opportunities," International Interactions 36, no. 3 (2010): 294-305; Andrew H. Kydd and Barbara F. Walter, "Sabotaging the Peace: The Politics of Extremist Violence," International Organization 56, no. 2 (2002): 263-96; Rose McDermott and Phillip G. Zimbardo, "The Psychological Consequences of Terrorist Alerts," in Psychology of Terrorism, edited by Bruce Bongar, Lisa M. Brown, Larry E. Beutler, James N. Breckenridge, and Philip G. Zambardo (New York, NY: Oxford University Press, 2007), 357-72.

59. David A. Lake, "Rational Extremism: Understanding Terrorism in the Twenty-First Century," Dialogue IO 1, no. 1 (2002): 15-29; Robert Pape, “The Strategic Logic of Suicide Terrorism," American Political Science Review 97, no. 3 (2003): 343-61.

60. Larry Isaac, Steve McDonald, and Greg Lukasik, "Takin' It from the Streets: How the Sixties Mass Movement Revitalized Unionization," American Journal of Sociology 112, no. 1 (2006): 46-96.

61. Haines, "Black Radicalization and the Funding of Civil Rights" (see note 3).

62. Sam Marullo and David S. Meyer, "Antiwar and Peace Movements," in The Blackwell Companion to Social Movements, edited by David A. Snow, Sarah A. Soule, Hanspeter Kriesi (Malden, MA: Blackwell Publishing LTD, 2004).

63. Lewis M. Killian, "The Significance of Extremism in the Black Revolution," Social Problems 20 (1972): 41-8.

64. Haines, "Black Radicalization and the Funding of Civil Rights" (see note 3); Haines, Black Radicals and the Civil Rights Mainstream (see note 3).

65. Jo Freeman, The Politics of Women's Liberation (New York, NY: Longman, 1975); Holly J. McCammon, Erin M. Bergner, and Sandra C. Arch, "Are You One of Those Women? Within-Movement Conflict, Radical Flank Effects, and Social Movement Political Outcomes," Mobilization 20, no. 2 (2015): 157-78. 
66. Isaac et al., "Takin' it from the Street" (see note 60).

67. Ellen Reese, Vincent Geidraitis, and Eric Vega, "Mobilization and Threat: Campaigns Against Welfare Privatization in Four Cities," Sociological Forces 38, no. 4 (2005): 287-309.

68. ibid.

69. Stacia Gilliard-Matthews, "The Impact of the Economic Downtown, Immigrants, and Political Representation on White Supremacist Group Organization in the United States," Sociological Forces 44, no. 3 (2011): 255-79.

70. Nella van Dyke and Sarah A. Soule, "Structural Social Changes \& the Mobilizing Effect of Threat: Explaining Levels of Patriot and Militia Organizing in the U.S.," Social Problems 49, no. 4 (2002): 497-520.

71. Chenoweth and Schock, "Do Contemporaneous Armed Challenges Affect the Outcomes of Mass Nonviolent Campaign?" (see note 4).

72. Gamson, The Strategy of Social Protest (see note 3).

73. Jack A. Goldstone, "The Weakness of Organization: A New Look at Gamson's The Strategy of Social Protest," American Journal of Sociology 85, no 5 (1980): 1017-42.

74. List, Radical Environmentalism (see note 6); Pellow, Total Liberation (see note 11).

75. Scarce, Eco-Warriors, 221 (see note 6).

76. Farrer and Klein, "The Political Roots of Domestic Environmental Terrorism" (see note 4).

77. Kuipers, Operation Bite Back (see note 6); List, Radical Environmentalism (see note 6).

78. Farrer and Klein, "The Political Roots of Domestic Environmental Terrorism" (see note 4).

79. List, Radical Environmentalism (see note 6).

80. Egan, Partisan Priorities (see note 40).

81. Omar Wasow, "Do Protests Matter?" (see note 3).

82. Gary C. Jacobson, "Terror, Terrain, and Turnout: Explaining the 2002 Midterm Elections," Political Science Quarterly 118, no. 1 (2002): 1-22.

83. George A. Bonanno and John T. Jost, "Conservatives Shift Among High-exposure Survivors of the September 11th Terrorist Attacks," Basic and Applied Social Psychology 28, no. 4 (2006): 311-23; James N. Breckenridge and Philip G. Zimbardo, "The Strategy of Terrorism and the Psychology of Mass-Mediated Fear," in Psychology of Terrorism, edited by Bruce Bongar, Lisa M. Brown, Larry E. Beutler, James N. Breckenridge and Philip G. Zambardo (New York, NY: Oxford University Press, 2007), 116-33; Green et al., "Hate Crime" (see note 40); Leonie Huddy, Stanley Feldman, and Erin Cassese, "On the Distinct Political Effects of Anxiety and Anger," in The Political Dynamics of Feeling and Thinking, edited by Ann Crigler, Michael MacKuen, George E. Marcus, and W. Russell Neuman, (Chicago, IL: University of Chicago Press, 2007), 202-30.

84. Agustin Echebarria-Echabe and Emilia Fernández-Guede, "Effects of Terrorism on Attitudes and Ideological Orientation," European Journal of Social Psychology 36 (2006): 259-65; Jeff Greenberg and Eva Jonas, "Psychological Motives and Political Orientation - the Left, the Right, and the Rigid: Comment on Jost et al. (2003)," Psychological Bulletin 129 (2003): 376-82.

85. Eric D. Gould and Esteban F. Klor, "Does Terrorism Work?" The Quarterly Journal of Economics 125, no. 4 (2010): 1459-510; Claude Berrebi and Esteban F. Klor, "Are Voters Sensitive to Terrorism? Direct Evidence from the Israeli Electorate," RAND Working Paper, 2008.

86. Deborah L. Guber, The Grassroots of a Green Revolution: Polling America on the Environment (Boston, MA: MIT Press, 2003).

87. Christopher Rootes, "Environmental Movements," The Blackwell Companion to Social Movements, edited by David A. Snow, Sarah A. Soule, Hanspeter Kriesi (Malden, MA: Blackwell Publishing LTD, 2004).

88. Kathleen Deloughery, Ryan D. King, and Victor Asal, "Close Cousins or Distant Relatives? The Relationship Between Terrorism and Hate Crime" Crime and Deliquency 58, no. 5 (2012): 663-88; Hirsch-Hoefler and Mudde, "Ecoterrorism" (see note 9). Lindsay Shorr Newman "Do Terrorist Attacks Increase Closer to Elections?" Terrorism and Political Violence 25, no. 1 (2013): 8-28; Valentina A. Bali, "Terror and Elections: Lessons from Spain," Electoral Studies 26, no. 3 (2007): 669-87; Claude Berrebi and Esteban F. Klor, "On Terrorism and Electoral Outcomes" Journal of Conflict Resolution 50, no. 6 (2006): 899-925; 
Berrebi and Klor, "Are Voters Sensitive to Terrorism?" (see note 85); Braithwaite et al., "Ballots, Bargains, and Bombs" (see note 58); Martin Gassebner, Richard Jong-A-Pin, and Jochen O. Mierau, "Terrorism and Electoral Accountability: Once Strike, You're Out!" Economics Letters 100, no. 1 (2008): 126-9; Anna Getmansky and Thomas Zeitzoff, "Terrorism and Voting: The Effect of Rocket Threat on Voting in Israeli Elections" American Political Science Review 108, no. 3 (2014): 588-604; Arzu Kibris, "Funerals and Elections: The Effects of Terrorism on Voting Behavior in Turkey" Journal of Conflict Resolution 55, no. 2 (2011): 220-47; Jennifer L. Merolla and Elizabeth J. Zechmeister, "Terrorist Threat, Leadership, and the Vote: Evidence from Three Experiments" Political Behavior 31, no. 4 (2009): 575-601.

89. Daphna Canetti-Nisim, Eran Halperin, Keren Sharvit, and Steven E. Hobfoll, "A New Stressbased Model of Political Extremism: Personal Exposure to Terrorism, Psychological Distress and Exclusionist Political Attitudes," Journal of Conflict Resolution 63, no. 2 (2009): 363-89; Getmansky and Zeitzoff, "Terrorism and Voting" (see note 88); Kibris, "Funerals and Elections" (see note 88); Weintraub et al., "Vote Choice and Legacies of Violence" (see note 3).

90. Lincoln Quillian, "Prejudice as a Response to Perceived Group Threat: Population Composition and Anti-immigrant and Racial Prejudice in Europe," American Sociological Review 60, no. 4 (1995): 586-611; Laura Dugan, Julie Y. Huang, Gary LaFree, and Clark McCauley, "Sudden Desistance from Terrorism: The Armenian Secret Army for the Liberation of Armenia and the Justice Commandos of the Armenian Genocide" Dynamics of Asymmetric Conflict 1, no. 3 (2008): 231-49.

91. There was a degree of endogeneity: variation in electoral support for Batasuna resulted in variation in ETA's target selection (de la Calle and Sánchez-Cuenca, "Killing and Voting in the Basque Country" (see note 57)).

92. McGrath and Gill, "An Exploratory Study on the Impact of Electoral Participation Upon a Terrorist Group's Use of Violence in a Given Year" (see note 59).

93. Bruce Hoffman, Inside Terrorism, 1st ed. (New York, NY: Columbia University Press, 1998).

94. ibid; Echebarria-Echabe and Fernández-Guede, "Effects of Terrorism on Attitudes and Ideological Orientation" (see note 84); Greenberg and Jonas, "Psychological Motives and Political Orientation - the Left, the Right, and the Rigid" (see note 84); Weintraub et al., "Vote Choice and Legacies of Violence" (see note 3).

95. Kollman et al., Constituency-Level Elections Archive (see note 8). For more details on the dependent variable see Farrer and Klein, "The Political Roots of Domestic Environmental Terrorism" (see note 4).

96. Result from Colorado's first district in 2006.

97. We examined different time windows, for example only events that occurred within three months of an election. However, too few events occurred in that timeframe for model reliability. An over-dispersion of 0 's is concerning if it occurs in the dependent variable and can be accounted for using Poisson or negative binomial model specifications, but when it occurs in the independent variable, as it does here (Twenty-Four Month FVES), it does not impede empirical interpretation of the variable or the results. Yet, we introduce a cubic spline of the variable to explore specific effects across changes in the distribution, but find that it does not improve model/predictive performance and does not show statistically significant differences in slope across the spline's knots.

98. The results are robust to allowing intercepts to vary by state in the multilevel model.

99. Although these variables are only available on the state level, they are a more valid measure of electoral progress than, for example, lagged vote shares, because it captures the difference between winning and losing, which matters for the perception of whether democratic methods have failed (Farrer and Klein, "The Political Roots of Domestic Environmental Terrorism" (see note 4)).

100. Results are also robust to including turnout as an independent variable, measured on the state level. 
101. These variables are coded as one if the only Democrat/Republican running in a district is the Democratic/Republican incumbent. It is coded as zero in other situations, such as when there are two incumbents, which can occur after redistricting.

102. de la Calle and Sánchez-Cuenca "Killing and Voting in the Basque Country" (see note 57).

103. It also removes the possibility of us finding a particular type of positive radical flank effect. If no candidate runs at $t-1$, and then a sabotage incident occurs, and the Green Party takes this as evidence of a strong environmental movement in the district and decides to field a candidate at $t$, then our data will not pick this up. However, this sequence of events only occurs five times in our dataset. A final endogeneity issue to consider is the possibility that the Green Party will refuse to field candidates if there has been sabotage. This is not incongruous with the theoretical picture we painted - it suggests that our causal mechanisms sometimes work preemptively.

104. Alan S. Gerber and Donald P. Green, Field Experiments: Design, Analysis, and Implementation (New Haven: Yale University Press, 2012).

105. In terms of frequency, there is no evidence that sabotage increases in the run-up to November elections, let alone ones where the Green Party might be expected to suffer a vote decline. In non-election years, $25 \%$ of events occur in September or October, whereas in election years it is $22 \%$. In terms of severity, GTD has incomplete information on the damage done by each incident. However, among the observations where property damage costs are recorded, there is no significant difference in means between the property damage from incidents in the September or October of election versus non-election years. In terms of target type, the only apparent difference is that more research facilities seem to be targeted in non-election years.

106. Farrer and Klein, "The Political Roots of Domestic Environmental Terrorism" (see note 4).

107. Andrew Gelman and Jennifer Hill, Data Analysis Using Regression and Multilevel/ Hierarchical Models (Cambridge, UK: Cambridge University Press, 2007).

108. William D. Berry, Jacqueline H. R. DeMeritt, and Justin Esarey, "Testing for Interaction in Binary Logit and Probit Models: Is a Product Term Essential?” American Journal of Political Science 54, no. 1 (2010): 248-66.

109. Except for lagged Green Party vote share, which we set at the somewhat higher level of $2.5 \%$ to make any backlash more distinguishable.

110. Scott J. Long and Jeremy Freese, Regression Models for Categorical Dependent Variables Using Stata, 2nd ed. (College Station, TX: StataCorp LP, 2006).

111. A few other coefficients stand out. First, the constants are very low, largely because we leave the "year" variable in its raw form. Second, the group standard deviations are substantially different in the two models. This suggests that Republican vote shares tended to be much more uniform across districts. We investigated whether these different standard deviations were the main driver of our results, but we obtained similar results using non-multilevel specifications.

112. Russell J. Dalton, Citizen Politics: Public Opinion \& Political Parties in Advanced Industrial Democracies, 3rd ed. (New York, NY: Chatham House, 2002, 59); Dunning, "Fighting and Voting"(see note 3); Leonard Weinberg, "Turning to Terror: The Conditions Under Which Political Parties Turn to Terrorist Activities," Comparative Politics 23, no. 4 (1991): 423-38.

113. Amster, "Perspectives on Ecoterrorism" (see note 9); Hirsch-Hoefler and Mudde, "Ecoterrorism" (see note 9).

114. Dalton, The Green Rainbow (see note 22); Doherty, Ideas and Actions in the Green Movement (see note 25); Daniel Q. Gillion, The Political Power of Protest: Minority Activism and Shifts in Public Policy (Cambridge: Cambridge University Press, 2013); McAdam et al., Comparative Perspectives on Social Movements (see note 3); John D. McCarthy and Mayer N. Zald, "Resource Mobilization and Social Movements: A Partial Theory," American Journal of Sociology 82, no. 6 (1977): 1212-41; Sidney Tarrow, Struggle, Politics, and Reform: Collective Action, Social Movements, and Cycles of Protest (Cornell: Cornell University Press, 1989). 


\section{Appendix}

In this document we provide the instructions and information necessary to replicate our results. We describe our data collection effort, our coding decisions, and the details of our analyses. Wherever possible, we provide links to online repositories for the actual software code and original data.

The replication instructions consist of three main parts. First, we use the U.S. Green Party website to create a database of the electoral history of the party from 1985 to 2005 (1985 being the earliest the website goes back to). We record, for each state, the total number of Green Party candidates that stood for election to any office in that state. We also count whether they stood for a local-level, state-level, or federal-level office, and whether or not they won their race. We supplement this with the actual vote percentage that candidates won-albeit only for Green Party candidates for U.S. House. This vote-percentage information comes from the Constituency Level Elections Database (CLEA). As well as recording the vote-percentage information for Green Party candidates for U.S. House, we also record how the Democratic and Republican candidates managed to do in the race. This, for each state, allows us to measure both how "active" the Green Party is in that state, and also how "successful" they were, and also how the other parties fared.

Second, we use the Global Terrorism Database (GTD) to find information on environmental sabotage in the U.S. over this same period. This database records where the incident happened, and which group perpetrated it. We use the latitude and longitude information from the GTD to place each incident in a Congressional District, and we also record how many days before a Congressional election it occurred.

Third, we add in a selection of control variables. These come from a variety of state-level and constituency-level databases, as described below. Once the data were compiled we conducted a series of analyses. We looked at multilevel linear regressions, as well as some simpler models, pooling the data but allowing for correlated errors. Since the multilevel models seemed more appropriate to the structure of the data, we only focus on those in the paper, but here we report other results as robustness checks. The following sections of the appendix describe each of these steps in more detail.

\section{Step One: Green Party Electoral History Database}

The Green Party of the USA keeps online records of their candidates. From 1985 onwards, their website at https://www.gpelections.org/lists the name of each candidate who ran, the jurisdiction they ran in and the office they ran for, and whether or not they won. For many but not all candidates, number of votes is also recorded, but since this was incomplete and was not accompanied by the vote totals of other candidates or by turnout information, this was not recorded.

Therefore we code the period from 1985 to 2005, and compile a variety of pieces of information. First, we collect the total number of candidates per-state year. Then we count how many won, and how many lost. We also count whether they ran for a local, state, or federal office, as follows:

We then use the six resulting variables - total local candidates, total local winners, total state candidates, total state winners, total federal candidates, and total federal winners-to code success rates per level of office per state over a five-year period. For example, in California, in 1990 there were seven local candidates: one for a city council seat, one for a water board seat, two for parks and recreation seats, one for sanitation, one for planning group, and one for residential council. Then in 1991 there were two local candidates, twenty-eight in 1992, two in 1993, and twenty-four in 1994. In 1994, then, there had been sixty-three locallevel candidates over the preceding five years. The number of winners was six in 1990, zero in 1991,

\begin{tabular}{lll}
\hline Local & State & Federal \\
\hline Mayor & State House & House of Representatives \\
Alderperson & State Senate & Senate \\
\hline
\end{tabular}




\begin{tabular}{lll}
\hline County Superintendent & Governor & President \\
\hline School Board & Lieutenant Governor & Vice-President \\
City Council & Secretary of State & State Treasurer \\
Town Council & Land Commission & \\
Water Board & Board of Trustees & \\
Parks and Recreation & Public Service Commission \\
Local Judicial Office & Board of Regents \\
Sanitation & Labour Commission \\
Planning Group & State Auditor \\
Residential Council & Comptroller \\
Borough Association & \\
District Attorney & \\
County Records Office & \\
Charter Commisioner & \\
County Sheriff & \\
Selectperson & \\
Municipal Judge & \\
Constable & \\
Board of Equalisers & \\
Hospital District & \\
Rent Stabilisation Board & \\
Freeholder & \\
\hline
\end{tabular}

twelve in 1992, one in 1993, and ten in 1994, for twenty-nine in total. This makes the "local-level failure percentage" equal to 53.96825 in 1995.

Step Two: Global Terrorism Database

We download the 2016 release of the GTD and keep all observations from the U.S. between 1984 and 2010. We classify as "ecoterrorist" any incident perpetrated by the following groups, i.e. if the "gname" variable in the GTD takes on any of the following values:

- Animal Liberation Front (ALF)

- Animal Rights Activists

- Earth First!

- Earth Liberation Front (ELF)

- Environmentalist

- Evan Mecham Eco-Terrorist International Conspiracy (EMETIC)

- Nuclear Liberation Front

- Revolutionary Cells-Animal Liberation Brigade

- The Justice Department

This returns 166 incidents from 1987 to 2010.

Step Three: Constituency Level Elections Database

We download the Constituency Level Elections Archive (CLEA) from its website at http://www. electiondataarchive.org/and then isolate only the data for the U.S. from 1984 onwards. These data include information for House of Representatives election, collected on the district level. So for each 
of the 435 congressional districts, we have the total electorate size, number of valid votes cast (allowing us to calculate turnout), and the vote totals for each candidate in the race.

When extracting Green Party Congressional Election results from this database it is important to bear in mind that local party system differences can change the way candidates list their affiliations. For example, most Green Party candidates were simply listed as "Green Party" but some were "Wisconsin Greens" or "Illinois Greens." In cases where there was any doubt about affiliation, the U.S. Green Party database was consulted, and the candidates name was cross-checked against the candidate names recorded by the central party. The cases where this was necessary are listed below:

- "Bolting greenback" NO is not included as Green Party because candidate name was not found in U.S. GP database.

- "Green" YES because candidate names match GP U.S. database

- "Green tea patriots" NO is not included as Green Party because candidate name was not found in U.S. GP database.

- "Greenback" NO is not included as Green Party because candidate name was not found in U.S. GP database.

- "Greenback democrat" NO is not included as Green Party because candidate name was not found in U.S. GP database.

- "Greenback labor" NO is not included as Green Party because candidate name was not found in U.S. GP database.

- "Illinois green" YES is included because candidate name matches U.S. database

- "Independent green" NO is not included because all candidate names do not match U.S. GP database

- "Independent (green)" YES is included because all candidate names match U.S. database

- "Independent maine greens" YES is included because all candidate names match U.S. database

- "Liberal/green" NO is not included because no candidate name is mentioned

- "Pacific green" YES is included because all candidate names match U.S. database

- "Pacific green progressive" YES is included because all candidate names match U.S. database

- "Preserve green space" NO is not included because all candidate names do not match U.S. GP database

- "Progressive, libertarian, pacific green" YES is included because all candidate names match U.S. database

- "t.b.a. green" YES is included because all candidate names match U.S. database

- "Vermont green" YES is included because all candidate names match U.S. database

- "Wisconsin green" YES is included because all candidate names match U.S. database

- "Write-in (green)" NO is not included because all candidate names do not match U. S. GP database

The CLEA includes 6,525 regular November elections from 1984 to 2012. In all but 330 of these, the Green Party vote percentage was zero. 